\title{
Epizootiological and genetic characterization of the bovine leukemia virus in the Russian federation - evaluation of bovine leukemia virus in Russia
}

\author{
Maxim Petropavlovskiy $^{1 *}$, Irina Donnik ${ }^{1,2}$, and Natalia Bezborodova ${ }^{1}$ \\ ${ }^{l}$ Federal State Budgetary Scientific Institution "Ural Federal Agrarian Scientific Research Centre, \\ Ural Branch of the Russian Academy of Sciences", Yekaterinburg, Russia \\ ${ }^{2}$ Ural State Agrarian University, Yekaterinburg, Russia
}

PETROPAVLOVSKIY, M., I. DONNIK, N. BEZBORODOVA: Epizootiological and genetic characterization of the bovine leukemia virus in the Russian federation - evaluation of bovine leukemia virus in Russia. Vet. arhiv 89, 785-798, 2019.

\section{ABSTRACT}

The genetic characterization of bovine leukemia virus (BLV) is an important task in scientific research in many countries of the world. According to the sequenced gene region - env BLV isolates have been found in different geographical locations of the world, and up to 10 different genetic groups of the virus have been identified and classified. As part of the research, we monitored the epizootic situation of the BLV in Russia. For grouping of animals $(n=54)$ Holstein-Frisian (imported breed) and Russian Black Pied (local breed) were selected, belonging to agricultural organizations in the Tyumen region. Serological screening methods (ELISA, AGID) were used in the cattle to identify infected animals. Immunological evaluation of the animals in all the test groups was also done. A primary A nested-PCR study was performed, which resulted in a fragment of the env $444 \mathrm{bp}$ gene in the studied samples. RFLP analysis of this fragment established that in $94 \%$ of the samples there was the «Belgian type» of the leukemia virus, in $4 \%$ of samples the «Australian» type, and in $2 \%$ - a «mixed type». The phylogenetic evaluation of the BLV genome env site in the isolated samples and the immunological evaluation of the infected animals helped to obtain new data that will enable information on the genetic groups of the BLV in the territory of the Russian Federation to be updated.

Key words: bovine leukemia virus; cattle; phylogenetic classification; serological screening; polymerase chain reaction; epizootic monitoring

\section{Introduction}

Bovine leukemia is a malignant lymphoproliferative disease, the etiological factor of which is the bovine leukemia virus (BLV), belonging to the genus Deltaretrovirus, of the family Retroviridae.

\footnotetext{
${ }^{*}$ Corresponding author:

Petropavlovskiy Maxim Valerievich, Candidate of Veterinary Sciences, Belinskogo str. 112A, Yekaterinburg, 620142, Russia, E-mail: viktorurgau@mail.ru
} 
The economic damage caused is due to the decrease in the qualitative and quantitative indicators of productivity, premature culling of highly productive individuals, high costs for utilization of bodies and organs with tumor lesions, and the great loss to breeding work due to the loss of the gene pool of valuable breeds (DONNIK, 2013).

The purpose of the research is to assess the epizootiological and phylogeographic spread of the bovine leukemia virus in the world, and in the territory of the Russian Federation.

The current epizootic situation in the world. The causative agent is widespread throughout the world, including the Russian Federation.

According to scientists from the University of Michigan (USA), $50 \%$ of all American dairy cattle are infected (OTT et al., 2003). According to the research of the US Department of Agriculture, $83 \%$ of dairy farms and $39 \%$ of meat farms in the USA have at least one infected animal (OTT et al., 2003). In Canada, the disease is registered in $89 \%$ of herds, with an infection rate of cattle at $20-40 \%$.

While the North American countries have chosen not to take serious measures in this regard, many other countries have decided to initiate control programs for BLV. The leukemia virus has been completely eradicated in 20 European countries and New Zealand (as of 2011). In addition, BLV has been eradicated from most regions of Poland, Portugal and Italy. The disease has been successfully eradicated among dairy herds in Western Australia, but a small percentage of infected cattle remain among the beef herds. The disease is widespread in herds in South America: Argentina (up to 90\%); Brazil (up to $60 \%$ ); Chile (up to $27.9 \%$ ); Bolivia (up to $30.7 \%$ ); Peru (up to $42.3 \%$ ); Venezuela (33.3\%); Paraguay (54.7\%). In Asia the disease is registered in $50 \%$ of dairy and $2 \%$ of meat farms in China, in Japan (up to 73.3\%), Mongolia (3.9\%), Cambodia (5.3\%), Taiwan (5.8\%), Iran (up to 29.8\%), Thailand (58.7\%), The Philippines (9.7\%), Korea (54.2\%), and Myanmar (9.1\%). In the Middle East it is found in Turkey (48.3\%), Israel (5\%) and Saudi Arabia (20.2\%) (POLAT et al., 2015).

In all entities in the Russian Federation serological screening is routinely carried out in order to identify animals infected with BLV; the results confirm the almost universal distribution of the virus. About 12-14 million cattle units are serologically examined and 3-4 million cattle units are hematologically examined every year in the Russian Federation.

According to the official data for 2017, 1876 locations were reported to be contaminated with BLV in the Russian Federation, with the infection rate of animals ranging from $15 \%$ (in some regions it is much higher), and the incidence rate $3-4 \%$ (the number of animals with the hematological stage in 2017 amounted to 29 thousand units). This epizootic situation has persisted for many years without any significant change. 
This disease has the largest share in the structure of infectious pathology of cattle in the Russian Federation (62\%). Cattle leukemia has been registered in the territory of 68 constituent entities of the Russian Federation.

Leukemia is also one of the most important problems for the livestock industry of the Ural region. An especially difficult epizootic situation persists in the Chelyabinsk and Kurgan regions. Due to targeted programs of anti-leukemic recreational measures adopted, which has been actively implemented in both the public and private sectors for a long time, the cattle population in the Sverdlovsk region is practically free of leukemia. Achievements in eradicating the disease have been attained mainly by testing and culling animals or isolating positive units. In the diagnosis of the disease, serological (AGID, ELISA) and molecular genetic (PCR) methods are used.

Molecular and genetic classification of BLV. Despite the relatively high efficiency of modern methods of diagnosing the disease, there is a possibility of incomplete identification of animals infected with the leukemia virus in healthy herds, which significantly affects the timing of targeted programs. Earlier it was noted that this could be due to the influence of the genetic variability of individual isolates of the virus (FELMER et al., 2005). The study of the genetic diversity of BLV is an important task of research in many countries of the world (BATENEVA et al., 2016; DONNIK et al., 2016; POLAT et al., 2015).

Like the other retroviruses, the BLV genome contains the structural and regulatory genes gag, pol and env proteins. The env gene encodes the transmembrane glycoproteins gp51 and gp30 of the virus capsid, which cause the infectivity of the virus, and is important in the serological diagnosis. In this regard, the phylogenetic analysis of genotypes of BLV has mainly been based on the env gene (POLAT et al., 2015).

We targeted a gene section - the env (444 bp - gp51 section), based on the fact that the extracellular protein gp51 plays a key role in the viral life cycle and is indispensable for integration into the host cells. In addition, the glycoprotein gp 51 is responsible for neutralizing antibodies due to its surface localization. Conformational epitopes, F, G and $\mathrm{H}$, which are localized in the N-terminal part of gp51, play a role in the formation of syncytium and viral infectivity. In this connection, the study of sequences of the env gp51section is usually used for the phylogenetic characterization of BLV (POLAT et al., 2015; ROLA-ŁUSZCZAK et al., 2013) (Fig. 1).

According to the sequencing of the gene region - env; in isolates of BLV isolated in different countries, up to 10 different genetic groups of the virus have been established and classified (PLUTA et al., 2018, BATENEVA et al., 2016; CAMARGOS et al., 2007; DONNIK et al., 2016; FELMER et al., 2005; LEE et al., 2016; LEE et al., 2015; LADRONKA, 2016; POLAT et al., 2015; POLAT et al., 2016; POLAT et al., 2017a; POLAT et al., 2017b; ROLA-ŁUSZCZAK et al., 2013; WANG et al., 2018; YANG et al., 2016). 


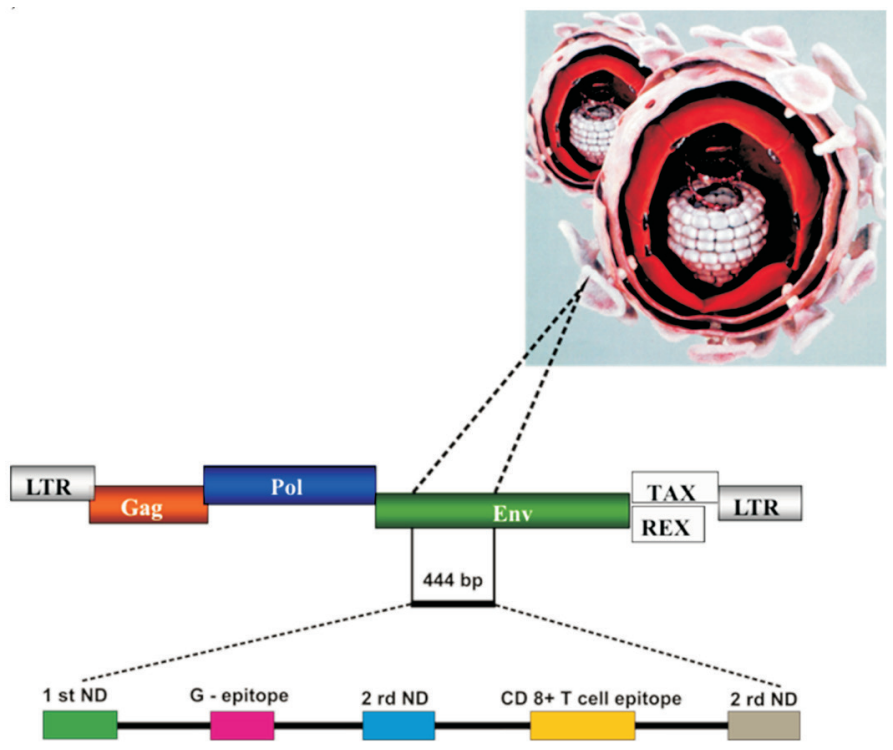

Fig. 1. The location of the $444 \mathrm{bp}$ env fragment with the structure of linear epitopes in the genome of BLV

Isolates from the Russian Federation that have been isolated and published in the NCBI Gen-Bank to date are classified in the genetic groups 4, 7, 8. All data are also based on the partial or complete sequencing of a section of the env - gp51 and gp30 gene from the regions of the Novosibirsk Region, the Vologda Region (G7), the Moscow Region (G4, G8) (POLAT et al., 2017a), Tyumen (G7 “Australian genotype”, G4 “Belgian genotype”), the Turin district of the Sverdlovsk region ("Australian genotype", G7) (DONNIK et al., 2016), Chelyabinsk region (G4 "Belgian genotype") and Krasnodar region (G7 “Australian”, G4 "Belgian” genotypes) (ROLA-ŁUSZCZAK et al., 2013). Analysis of the amino acid sequences of the isolated strains revealed that the main changes were localized in the $\mathrm{C}$ part of the CD4 + epitope, the zinc binding peptide region, the CD8 + $\mathrm{T}$ cellular epitope and the overlapping linear epitope $\mathrm{E}$, and the largest number of changes was noted in G4 ("Belgian genotype") (DONNIK et al., 2016; ROLA-ŁUSZCZAK et al., 2013). It is assumed that the point mutations identified in the genome of the pathogen indicate the adaptive features of the virus in the process of evolution.

Studies conducted on the genetic characteristics and classification of isolates of BLV from Eastern Europe and Russia are not comprehensive. 
Objects of the research. We selected groups of cows (54 units in each) of 3-4 years of age of Holstein Friesian (imported) breed and Russian Black Pied (local) breed, belonging to agricultural organizations in 2 districts of the Tyumen region.

The choice of agricultural organizations of the Tyumen region was due to the epizootic situation: the level of infection with leukemia virus at these enterprises was more than $30 \%$, with the average infection rates of areas $2.5 \%$ and $1.7 \%$. Imported cattle were brought into the territory of the Russian Federation from the Netherlands in JanuaryFebruary 2014. All imported animals were negative for the leukemia virus, which was confirmed by mandatory serological control during the registration of veterinary certification documents.

However, at the time of the study, in 2017, the cattle were infected with leukemia virus. The alleged source of infection could be local and imported livestock (previously imported in 2011 from the United States). It is also possible that there were false-negative serological tests in a batch of cattle from the Netherlands.

Research methods. We carried out a selection of methods for research into the genome of the leukemia virus isolates. Serological (ELISA, AGID) methods of screening the cattle population were used to identify infected animals. Studies of the samples in ELISA were performed using an IDEXX Leukosis Serum Screening test, manufactured by IDEXX, Montpellier SAS, France, using the kit for detecting antibodies to the bovine leukemia virus.

We used a diagnostic kit produced by the Kursk Biofactory - the company "BIOK", for the AGID diagnosis.

Primary PCR - a biomaterial study was performed using a standard commercial test system. DNA isolation from the blood and PCR were performed in accordance with the manufacturer's test system instructions. In this study, a reagent kit for DNA extraction "Diatom DNA Prep 200" by "IsoGen" (Moscow) was used.

In order to diagnose DNA samples for BLV, the commercial test kit "GenPak DNA PCR test for DNA amplification of Bovine leukemia virus" was used, by "IzoGen" (Moscow).

A nested PCR reaction was used in order to amplify a short section of the gene. Complementary DNA primers and components of the PCR mixture were selected for the reaction. The env gene fragment was amplified using Nested PCR using the following primers: env 5032 tct-gtg-cca-agt-ctc-cca-gat-a, env 5608 aac-aac-aac-ctc-tgg-gaa-ggg-t, env 5099 ccc-aca-agg-gcg-gcg-ccg-gtt-t, env 5521 gcg-agg-ccg-ggt-cca-gag-ctg-g [17], synthesized by "Syntol" (Moscow). Nested PCR was performed by conducting two consecutive reactions. For carrying out nested PCR, a set of BioMaster HS-Tag PCR $\left(2^{x}\right)$ by "Biolabmix" (Novosibirsk) was used. The concentrations of the solutions and the temperature regimes of the amplification reaction were established experimentally, and a 
research protocol was formed. As a control experiment, DNA isolated from cell culture FLK-BLV was used. The DNA concentration was measured on a MaxLife H100 Mod.2 kit by "MVM Diagnostics" (Barnaul). As a result of the study, it was found that when nested PCR was set up, the reaction proceeded better in the first stage using the genomic DNA obtained, at a concentration of $500 \mathrm{ng}$ and an external primer in the amount of 1.0 $\mu \mathrm{L}(1 \mathrm{pkm} / \mu \mathrm{L})$ per sample. In horizontal electrophoresis, amplicons, which corresponded to a fragment length of $600 \mathrm{bp}$ and were well viewed at a visual assessment, were used for formulation of the second stage of Nested PCR, with a 1: 100 dilution of the obtained PCR product. Following a negative result in the first stage of the Nested PCR, amplification products were used without dilution for the second stage. Amplification was performed using an Appliede Biosystems 2720 thermal cycler (Singapore) with the following cycle parameters: 2 minutes at $94{ }^{\circ} \mathrm{C}(1$ cycle $), 30$ seconds at $95{ }^{\circ} \mathrm{C}, 30$ seconds at $62{ }^{\circ} \mathrm{C}$ (external primers) or 30 seconds at $70{ }^{\circ} \mathrm{C}$ (internal primers), 60 seconds at $72{ }^{\circ} \mathrm{C}(40$ cycles), 4 minutes at $72{ }^{\circ} \mathrm{C}$. The PCR was performed in a $50 \mu \mathrm{L}$ volume of the reaction mixture per sample $\left(25 \mu \mathrm{L}\right.$ BioMaster set HS-Tag PCR $\left(2^{\mathrm{x}}\right), 1.0 \mu \mathrm{L}$ of each primer $(1$ $\mathrm{pkm} / \mu \mathrm{L}), 1 \mu \mathrm{L} \mathrm{MgCl}_{2}(50 \mu \mathrm{M}), 500 \mathrm{ng}$ of genomic DNA, diluted bidistilled water. The reaction was recorded by horizontal electrophoresis, using a $1.5 \%$ agarose gel with the addition of ethidium bromide as an intercolating dye for DNA. The equipment used in the study was a mini-camera Mini-Sub Cell GT by "Bio-Rad" (USA) with a Bio-Rad CHEMIDOC XRS+ camera for ultraviolet imaging (USA). After the PCR was performed with primers, the "Step100" marker by "Biolabmix" (Novosibirsk) was used. At the first stage of the Nested PCR test, the samples were taken as positive, containing amplicons, whose electrophoretic mobility corresponded to a fragment length of $600 \mathrm{bp}$. In the second stage of Nested PCR, positive amplicons corresponded to a length of $444 \mathrm{bp}$.

As a control experiment, the cell line FLK BLV (the kidney of a sheep embryo) was used [J. Natl. Cancer Inst. 1974. 52: 491; Bibl. Haemotol. 1976. 43: 360; Canad. J. Comp. Med. 1981. 45: 154; Virology 1982. 122: 353; J. Virol. Meth. 1983. 6: 19; Vopr. Virus. 1983. 5: 615]. The culture produced the bovine leukemia virus. The monolayer method of cultivation was used (Fig. 2). Cultivation was carried out on the 199 medium with the addition of $10 \%$ bovine fetal serum. The reseeding procedure included the removal of cells using Versen $0.02 \%$ with $0.1 \mathrm{mg} / \mathrm{mL}$ of chemopsin, and the multiplicity of sieving corresponded to $1: 3$, at a density of $1 \times 10$ in 5 cells $/ \mathrm{mL}$. Cryopreservation was carried out under the following conditions: BME $80 \%$, fetal bovine serum $10 \%$, glycerol $10 \%$. Then $3 \times 10^{6}$ cells $/ \mathrm{mL}$ were aliquoted in a vial. 


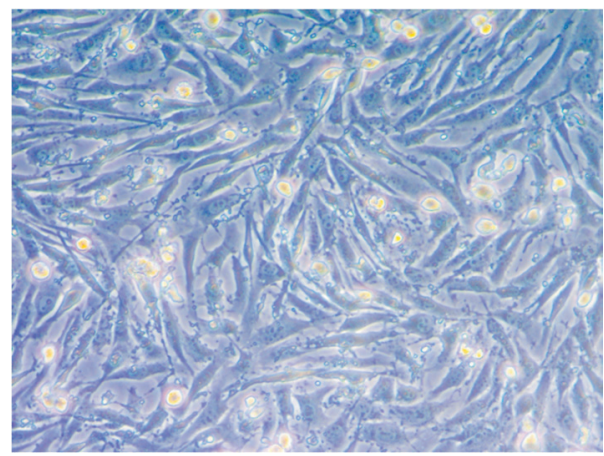

Fig. 2. Monolayer cells formed on FLK BLV culture

The CC81 cell line was used as the permissive cell culture. We used feline fetal lung fibroblasts transformed with Moloni sarcoma virus [J. Virol. 1973. 11: 978; 1974. $14 ; 177]$. We used the monolayer method of cultivation. The nutrient medium used was Igla MEM medium with L-glutamine and a double set of amino acids (Biolot, Russia), with the addition of fetal calf serum (PAA Laboratories, USA), in 10\% concentration. We warmed the serum at $56{ }^{\circ} \mathrm{C}$ for 30 minutes for sterilization. The cell culture was cultivated in plastic bottles (TPP, Switzerland) at $37{ }^{\circ} \mathrm{C}$ with a complete change of medium 3 times a week. The removal of cells was performed using Versen $0.02 \%$ with chemopsin $0.1 \mathrm{mg} / \mathrm{mL}$, the multiplicity of sieving 1:6 - 1:10, with optimal density of $0.6 \times 10$ per 5 cells $/ \mathrm{mL}$. Cryopreservation was performed with the following parameters: DMEM $70 \%$, fetal bovine serum $20 \%$, glycerol $10 \%, 2-3 \times 10$ per 6 cells $/ \mathrm{mL}$ in the ampoule. The cell culture was stained according to the Grunwald-Giems method. Blood samples were taken for infection of cell cultures in vacuum tubes $(10 \mathrm{~mL})$ with EDTA, and we prepared a leukocyte suspension containing not less than $5 \times 10$ in $6 / \mathrm{mL}$ of cells resuspended in $10 \%$ medium, with the addition of the antibiotics amphotericin $(5 \mathrm{U} / \mathrm{mL})$, penicillin, and streptomycin $\left(100 \mathrm{U}\left(\mu \mathrm{g} / \mathrm{cm}^{3}\right)\right)$. The positive reaction was characterized by the disruption of the cell monolayer of the permissive culture, and the formation of a cluster of multinucleated cells (Fig. 3). This technique was used for virus accumulation and subsequent analysis of the pathogen genome.

To conduct genotyping of the env section (444bp-gp51 section), a polymorphism reaction (RFLP) was used; BamHI, BclI, PvuII were used as restriction enzymes.

Amplification was performed using an Appliede Biosystems 2720 thermal cycler (Singapore) with the following cycle parameters: BamHI, PvuII $-37^{\circ} \mathrm{C}$ for 2 hours; BclI $-55^{\circ} \mathrm{C}$ for 2 hours. The PCR was performed in a volume of the reaction mixture of $20 \mu \mathrm{L}$ per sample ( $5 \mu \mathrm{L}$ of PCR product, $1 \mu \mathrm{L}$ of the enzyme, $2 \mu \mathrm{L}$ of buffer, $12 \mu \mathrm{L}$ of bidistilled water). 
M. Petropavlovskiy et al.: Characterization of the bovine leukemia virus in the Russian Federation

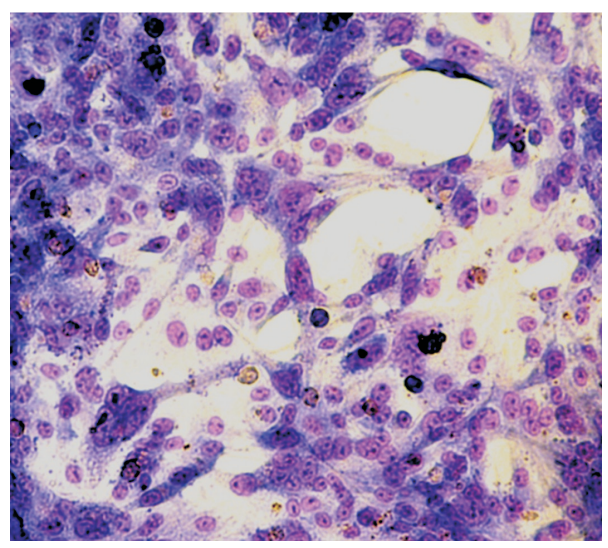

Fig. 3. Syncyte formation in the cell monolayer CC81

\section{Results}

Of the 54 samples tested by the Nested PCR method for the presence of bovine leukemia virus, 48 samples revealed a specific DNA segment of the leukemia virus, which was $100 \%$ consistent with the methods of serological identification (ELISA).

The results of Nested PCR for the presence of leukemia virus DNA were also compared with parallel studies on a commercial test system. In a comparative assessment, it was found that three samples (No. 1, 5,9) turned out to be negative when examine using a commercial test system; however, the Nested PCR method in these samples revealed the DNA of the leukemia virus (Fig. 4. A, B).
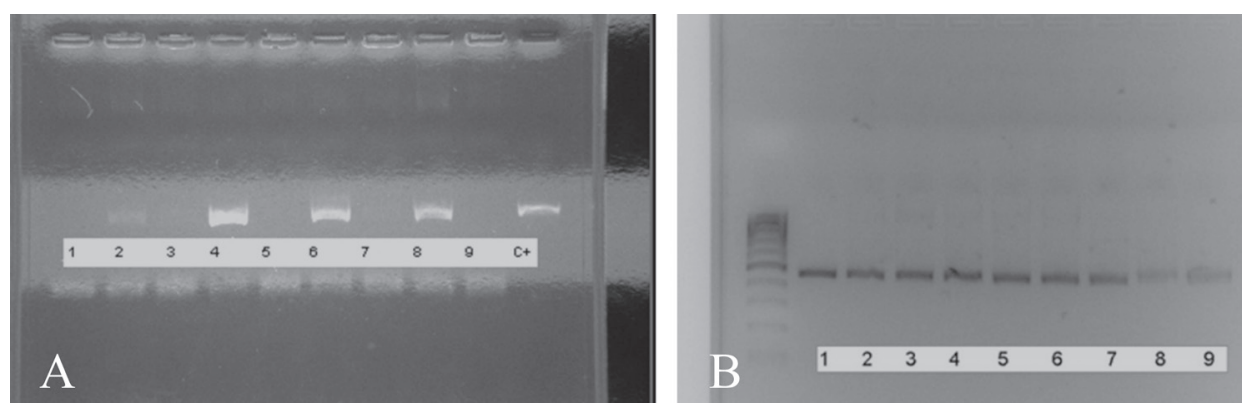

Fig. 4. Electrophoregram amplification products: $M$ - marker M100 increments; BLV+ (2, 3, 4, 6, 7, $8)$ - animals infected with BLV amplified with a commercial kit (A) and amplified using the Nested PCR method (second stage) (B); C+ - positive control sample (1, 2, 3, 4, 5, 6,7, 8, 9 - BLV+) 
These samples were selected from a group of local cattle from the Tyumen district of the Tyumen region. We believe that obtaining false-negative results in $6.25 \%$ of the samples could be associated with the low concentration of proviral DNA, which could affect the sensitivity of the commercial test system. The Nested PCR formulation is performed on two pairs of primers (external and internal), which allows a significant increase in the concentration of the original DNA due to 2 amplifications. Also after DNA isolation, we measured its concentration (500 ng of genomic DNA in $1 \mu \mathrm{L}$ ), which accordingly increased the sensitivity of this method. This could also be related to the local variability of the gene section at the primer planting section using the commercial test system.

A nested PCR study was performed, which resulted in the generation of a fragment of the env $444 \mathrm{bp}$ gene in the samples $(\mathrm{n}=48)$.

To conduct genotyping of the env section (444bp-gp51 region), a polymorphism reaction was performed, further analyzing the size of the resulting fragments (restricts) by gel electrophoresis. The results of the conducted restriction were taken into account in accordance with the tabular data (Table 1).

Table 1. Distribution of restriction sites by genotypes depending on restricts

\begin{tabular}{|l|c|c|c|}
\hline BLV type & BamHI & PvuII & BclI \\
\hline Japaneese & $316 ; 128$ & 444 & $219 ; 121 ; 104$ \\
\hline Australian & $316 ; 128$ & 444 & $225 ; 219$ \\
\hline Belgian & 444 & $280 ; 164$ & $225 ; 219$ \\
\hline
\end{tabular}

During the RFLP analysis in the two studied samples (No. 8CH, 19F), the Australian genotype of leukemia virus was found to be consistent. When subjected to restriction enzymes, the length of the restriction sites corresponded to the following indicators: BamHI - 316, 128 bp; PvuII - 444 bp; BclI - 225, 219 bp (Fig. 5 A, C). These samples originated from the Tyumen and Nizhne-Tavdinsky districts of the Tyumen region. We established a sample (No. $23 \mathrm{CH}$ ) from the Tyumen region, which could not be classified as any of the genotypes according to the scheme presented, so we attributed it to the "mixed genotype" where the lengths of the restriction sites corresponded to the following: BamHI - 444 bp; PvuII - 444 bp; BclI - 225, 219 bp) (Fig. 5 B).

The rest of the studied samples, according to Table 1, were assigned to the "Belgian genotype" with the following indicators of the length of restriction sites: BamHI - $444 \mathrm{bp}$; PvuII - 280, 164 bp; BclI - 225, 219 bp (Fig. 5 A, B, C). 
M. Petropavlovskiy et al.: Characterization of the bovine leukemia virus in the Russian Federation

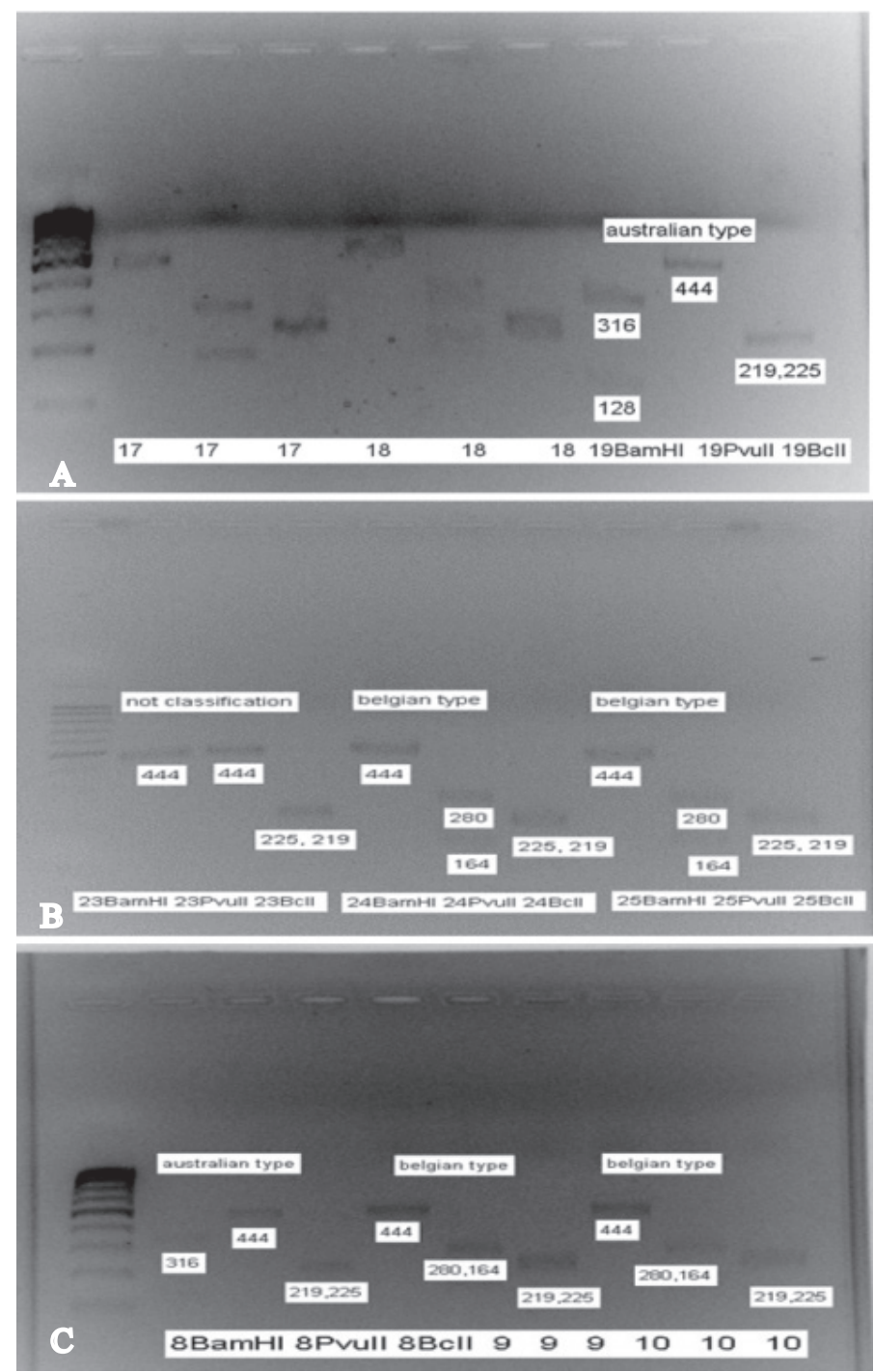

Fig. 5. Electrophoregram of the distribution of restriction sites during the RFLP reaction: $M$ marker M100 increments; "Australian genotype" of the virus (A, C); "Unclassified genotype" of the virus (B), "Belgian genotypes" of the virus $(B, C)$ 
Research conducted in the territories of 2 districts of the Tyumen region established the dominant value ( $94 \%$ of the studied samples) of the "Belgian genotype" of BLV.

All samples were sent for DNA sequencing at the "Sintol" and "Evrogen" enterprises, and further conclusions will be made from the results of the reaction. Phylogenetic and immunobiological assessment of the pathogen genome will be made. The data obtained will help us to obtain new data, allowing us to update information about the genetic groups of BLV in the territory of the Russian Federation.

\section{Discussion and conclusions}

It is well-known that the bovine leukemia virus is widespread throughout the world, including the Russian Federation. 1876 locations contaminated with BLV have been registered in the Russian Federation. Bovine leukemia is registered in the territory of 68 constituent entities of the Russian Federation, including the Ural region. The disease has the largest share in the structure of infectious pathology of cattle in the Russian Federation (62\%). This epizootic situation has persisted for many years without any significant change.

Of the 54 samples tested by the Nested PCR method for the presence of bovine leukemia virus, 48 samples detected a specific DNA segment of the leukemia virus, which was $100 \%$ consistent with the methods of serological identification (ELISA).

The study of the 444 bp gene fragment, using the enzyme polymorphism method (RFLP), established that the "Belgian genotype" of the leukemia virus was present in 94\% of the samples; the "Australian genotype" was found in 4\% and a "Mixed genotype" in $4 \%$ of the samples. It has therefore been established that in this region of the Russian Federation the "Belgian genotype" dominates the "Australian genotype". It should also be noted that according to the data obtained by DONNIK et al., 2016, and ROLAŁUSZCZAK et al., 2013, the "Australian genotype" dominated in the Tyumen region, however, more extensive studies in this direction, presented in this publication, indicate the replacement of this genotype with the "Belgian genotype" over the course of time.

All the samples were sent for DNA sequencing at "Sintol" and "Evrogen" enterprises, and further conclusions will be made from the results of the reactions. Phylogenetic and immunobiological assessment of the pathogen genome will be made. The data obtained will help us to obtain new data, allowing us to update information about the genetic groups of the bovine leukemia virus in the territory of the Russian Federation. 
M. Petropavlovskiy et al.: Characterization of the bovine leukemia virus in the Russian Federation

\section{Acknowledgements}

This research was carried out with the support of a Russian science foundation grant (project no. 17-76-10051).

\section{Conflict of interest}

The authors confirm that the presented data do not contain a conflict of interest.

\section{References}

BATENEVA, N. V., P. N. SMIRNOV, S. H. VYSHEGUROV, M. S. FOMENKO, M. I. VOEVODA (2016): Features of the regional structure of the BLV provirus. Res. J. Pharm. Biol. Chem. Sci. 7, 2025-2032.

CAMARGOS, M. F., A. PEREDA, D. STANCEK, M. A. ROCHA, J. K. DOS REIS, I. GREISERWILKE, R. C. LEITE (2007): Molecular characterization of the env gene from Brazilian field isolates of Bovine leukemia virus. Virus Genes. 34, 343-350.

DOI: $10.1007 / \mathrm{s} 11262-006-0011-\mathrm{x}$

DONNIK, I. M. (2013): Determination of the prevalence dynamics of bovine leukemia in the Russian Federation. Agrarian Bullertn of the Urals. 107, 25-27 (In Russian).

DONNIK, I., M. PETROPAVLOVSKY A. S. KRIVONOGOVA, I. A. SHKURATOVA, R. L. MARZENA, K. JACEK (2016): Revisiting the issue of the molecular-genetic structure of the causative agent of the bovine leukemia virus in the Russian Federation. Ind. J. Sci. Tech. 9, $1-11$.

DOI: $10.17485 / \mathrm{ijst} / 2016 / \mathrm{v} 9 \mathrm{i} 42 / 104253$

FELMER, R., G. MUÑOZ, J. ZÚÑIGA, M. RECABAL (2005): Molecular analysis of a 444 bp fragment of the bovine leukaemia virus gp51 env gene reveals a high frequency of non-silent point mutations and suggests the presence of two subgroups of BLV in Chile. Vet. Microbiol. 108, 39-47.

DOI: $10.1016 /$ j.vetmic.2005.04.005

LEE, E., E. J. KIM, J. RATTHANOPHART, R. VITOONPONG, B. H. KIM, I. S. CHO, J. Y. SONG, K. K. LEE, Y.K. SHIN (2016): Molecular epidemiological and serological studies of bovine leukemia virus (BLV) infection in Thailand cattle. Infect. Genet. Evol. 41, 245-254.

DOI: 10.1016/j.meegid.2016.04.010

LEE, E., E. J. KIM, H. K. JOUNG, KIM B. H., SONG J. Y., CHO I.S., LEE K.K., SHIN Y.K. (2015): Sequencing and phylogenetic analysis of the gp51 gene from Korean bovine leukemia virus isolates. Virol. J. 12.

DOI: $10.1186 / \mathrm{s} 12985-015-0286-4$

LADRONKA, R. (2016): Impact of bovine leukemia virus on herd level production indicators on U.S. dairy farms. In: $97^{\text {th }}$ Annual Meeting of the Conference of Research Workers in Animal Diseases. Chicago, IL. 
M. Petropavlovskiy et al.: Characterization of the bovine leukemia virus in the Russian Federation

OIE (2009): World Organization for Animal Health. World animal health infromation databaseversion: 1.4. Paris France: World Organisation for Animal Health.

OIE (2018): World Organization for Animal Health. Enzootic Bovine Leukosis. World Anim Heal Inf Database, Dis information, List Ctries by Sanit Situat. Available at: http://www.oie.int/ wahis_2/public/wahid.php/Diseaseinformation/statuslist

OTT, S. L., R. JOHNSON, S. J. WELLS (2003): Association between bovine leukosis virus seroprevalence and herd-level productivity on US dairy farms. Prev. Vet. Med. 61, 249-262.

DOI: 10.1016/j.prevetmed.2003.08.003

PLUTA, A., M. ROLA-ŁUSZCZAK, P. KUBIS', S. BALOV, R. MOSKALIK, B. CHOUDHURY, J. KUZMAK (2018): Molecular characterization of bovine leukemia virus from Moldovan dairy cattle. Arch. Virol. 162, 1563-1576.

DOI: $10.1007 / \mathrm{s} 00705-017-3241-4$

POLAT, M., A. OHNO, S. N. TAKESHIMA, J. KIM, M. KIKUYA, Y. MATSUMOTO, C. N. MINGALA, M. ONUMA, Y. AIDA (2015): Detection and molecular characterization of bovine leukemia virus in Philippine cattle. Arch. Virol. 160, 285-296.

DOI: 10.1007/s00705-014-2280-3

POLAT, M., S. N. TAKESHIMA, K. HOSOMICHI, J. KIM, T. MIYASAKA, K. YAMADA, M. ARAINGA, T. MURAKAMI, Y. MATSUMOTO, V. DE LA BARRA DIAZ, C. J. PANEI, E. T. GONZÁLEZ, M. KANEMAKI, M. ONUMA, G. GIOVAMBATTISTA, Y. AIDA (2016): A new genotype of bovine leukemia virus in South America identified by NGS-based whole genome sequencing and molecular evolutionary genetic analysis. Retrovirology 13.

DOI: 10.1186/s12977-016-0239-Z

POLAT, M., S. N. TAKESHIMA, Y. AIDA (2017a): Epidemiology and genetic diversity of bovine leukemia virus. Virol. J. 14.

DOI: $10.1186 / \mathrm{s} 12985-017-0876-4$

POLAT, M., H. H. MOE, T. SHIMOGIRI, K. K. MOE, S. N. TAKESHIMA, Y. AIDA (2017b): The molecular epidemiological study of bovine leukemia virus infection in Myanmar cattle. Arch. Virol. 162, 425-437.

DOI: $10.1007 / \mathrm{s} 00705-016-3118-\mathrm{y}$

ROLA-ŁUSZCZAK, M., A. PLUTA, M. OLECH, I. DONNIK, M. PETROPAVLOVSKIY, A. GERILOVYCH, I. VINOGRADOVA, B. CHOUDHURY, J. KUZ'MAK (2013): The molecular characterization of bovine leukemia virus isolates from Eastern Europe and Siberia and its impact on phylogeny. PLoS One. Vol. 8.

DOI: 10.1371/journal.pone.0058705

WANG, M., Y. WANG, A. R. BALOCH, Y. PAN, F. XU, L. TIAN, Q. ZENG (2018): Molecular epidemiology and characterization of bovine leukemia virus in domestic yaks (Bos grunniens) on the Qinghai-Tibet Plateau. China. Arch. Virol. 163, 659-670.

DOI: $10.1007 / \mathrm{s} 00705-017-3658-9$ 
M. Petropavlovskiy et al.: Characterization of the bovine leukemia virus in the Russian Federation

YANG, Y., P. J. KELLY, J. BAI, R. ZHANG, C. WANG (2016): First molecular characterization of bovine leukemia virus infections in the Caribbean. PLoS One. 11.

DOI: 10.1371/journal.pone.0168379

Received: 3 December 2018

Accepted: 1 February 2019

\section{PETROPAVLOVSKIY, M., I. DONNIK, N. BEZBORODOVA: Epizootiološka i genska svojstva virusa goveđe leukemije s područja Ruske Federacije. Vet. arhiv 89, 785-798, 2019.}

\section{SAŽETAK}

Genska svojstva virusa goveđe leukemije (BLV) važan su dio znanstvenih istraživanja u mnogim zemljama u svijetu. Prema sekvenciranoj regiji gena - env BLV izolati nalaze se u različitim područjima širom svijeta te je dokazano i klasificirano do deset različitih genskih skupina. Kao dio istraživanja pratili smo epizootiološki status BLV-a u Rusiji. Za pokusne životinje $(\mathrm{n}=54)$ odabrane su holštajnsko-frizijska pasmina (uvozna pasmina) $\mathrm{i}$ rusko šaro goveda (lokalna pasmina), koje potječu s poljoprivrednih dobara regije Tyumen. Kako bi se otkrile zaražene jedinke, upotrijebljene su serološke metode probira (ELISA, AGID). Također je u svim pokusnim skupinama provedena imunološka procjena životinja. Primijenjena je primarna A-nested-PCR analiza koja je rezultirala fragmentom gena env $444 \mathrm{bp}$. RFLP. Analizom tog fragmenta u $94 \%$ uzoraka ustanovljen je belgijski tip virusa leukemije, u $4 \%$ uzoraka australijski tip, a u $2 \%$ mješoviti tip. Filogenetskom procjenom genoma env BLV-a u izoliranim uzorcima i imunološkom procjenom zaraženih životinja dobiveni su najnoviji podaci o genskim skupinama BLV-a u Ruskoj Federaciji.

Ključne riječi: virus goveđe leukemije; goveda; filogenetska klasifikacija; serološki probir; reakcija lančane polimeraze; epizootiološko praćenje 